\title{
MIGRATION EXPERIENCES IN SELECTED WORKS BY STANISLAV STRUHAR
}

\section{Gabriela Šilhavá}

J. E. Purkyně University. Ústí nad Labem, Czech Republic. Email: gabina.silhava[at]seznam.cz

\begin{abstract}
Stanislav Struhar, nowadays one of the most productive contemporary Austrian authors, has published 12 works so far. The main themes of his works include the integration of a migrant who loses and finds his home, the associated language change, the search for happiness in the new home or the conscious rejection of the traumatic past. This also corresponds to the fact that the main characters in almost all of his prosaic works are migrants or their descendants. Stanislav Struhar also shows that love and language are of particular importance for the integration of migrants into the foreign milieu. The article analyzes the ambivalent character of migration experiences and the positioning of migrants in foreign society using the example of the novels Das Manuskript (2002), Eine Suche nach Glück (2005) and the volume of short stories Fremde Frauen (2013). In the first work the main characters are confronted with physical violence, in other two works it is more about the migrants' feelings of foreignness, stereotypes and prejudices, with which they are confronted. In this context, the attitude of the protagonists towards the language, both the foreign language and their mother tongue, should also be emphasized.
\end{abstract}

\section{Keywords}

austrian literature; foreignness; integration; language; migration; migration experiences; migrant literature; novel; Stanislav Struhar; stereotypes

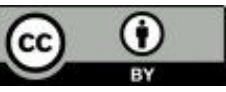

This work is licensed under a Creative Commons «Attribution» 4.0 International License 


\title{
МИГРАЦИОННЫЙ ОПЫТ В ИЗБРАННЫХ РАБОТАХ СТАНИСЛАВА СТРУГАРА
}

\section{Шилхава Габриэла}

Университет Яна Евангелиста Пуркине. Усти-над-Лабем, Чехия. Email: gabina.silhava[at]seznam.cz

\begin{abstract}
Аннотация
Станислав Стругар, ныне один из самых продуктивных австрийских авторов современности, опубликовал к настоящему времени 12 работ. Основные темы его произведений включают интеграцию мигранта, который теряет и находит свой дом, связанные с этим языковые изменения, поиск счастья в новом доме или сознательный отказ от травмирующего прошлого. Это также соответствует тому, что главные герои почти всех его прозаических произведений мигранты или их потомки. Станислав Стругар показывает также, что любовь и язык имеют особое значение для интеграции мигрантов в иностранную среду. В статье анализируется амбивалентный характер миграционного опыта и позиционирования мигрантов в иностранном обществе на примере романов Das Manuskript («Рукопись», 2002), Eine Suche nach Glück («Поиск счастья», 2005) и сборника рассказов Fremde Frauen («Чужие женщины», 2013). В первом произведении главные герои сталкиваются с физическим насилием, в двух других речь больше идет о чувстве чужеродности, о стереотипах и предрассудках мигрантов, с которыми они сталкиваются. В этом контексте важно подчеркнуть отношение главных героев к языку, как к иностранному, так и к своему родному.
\end{abstract}

\section{Ключевые слова}

австрийская литература; чужеродность; интеграция; язык; миграция; опыт миграции; литература мигрантов; роман; Станислав Стругар; стереотипы

Это произведение доступно по лицензии Creative Commons «Attribution» («Атрибуция») 4.0 Всемирная 


\section{INTRODUCTION}

Stanislav Struhar ( ${ }^{*} 1964$, Gottwaldov, Czechoslovakia) today a successful contemporary Austrian author, spent his childhood and youth in the then Czechoslovak Socialist Republic. His life in the country, which was under the rule of the Communist Party, had been so unfortunate for him that he finally fled from the country with his wife in 1988.

Their officially approved trip led at that time to Yugoslavia. The couple was allowed to leave Czechoslovakia under one specific condition: their son stays in the country. ${ }^{1}$ Struhar and his wife agreed, they had already received information from friends who had emigrated earlier that they could apply to the Red Cross for help with the subsequent departure of their son (as part of the reunification of the family). Stanislav Struhar and his wife fled from Yugoslavia illegally to Austria, where they were waiting for their son and wanted to continue their journey to California. In Austria, however, they were shocked when they discovered that Czechoslovakia no longer cooperates with the Red Cross. The reunion with their son was only possible after a two-year struggle with the authorities in both countries. When their son finally came to Austria in 1990, this country has already become their new home, so they stayed there. ${ }^{2}$

Their beginnings in Austria were not easy. Struhar had to learn German first. But when he had learned German ${ }^{3}$, it became his literary language. Today all of his works are published in both languages, German and Czech, which is not quite common. And because Stanislav Struhar speaks both languages, he takes an active part in the translations of his works. Today he no longer dares to translate his works into Czech on his own, but he can still read and correct the translations (both Czech and German). He has published 12 works so far - one volume of poetry (1999 Der alte Garten), four volumes of short stories (2013 Fremde Frauen, 2016 Farben der Vergangenheit, 2018 Fremde Männer, 2021 Farben der Zukunft) and seven novels

1 At that time everyone had to get permission from the ministry to travel to foreign countries, including Yugoslavia (Tito took his own socialist path that was not in conformity with Stalinism). For this reason, the Struhars were only allowed to travel to Yugoslavia without their child, as it was assumed that the parents would not leave their child behind in Czechoslovakia. The child was therefore meant to be used as a 'guarantee' for their return home.

2 It was often the case that the migrants originally did not want to stay in Austria. As Cornejo (2008, p. 59) points out, at that time Austria often only played the role of a 'transit camp'. Stanislav Struhar e.g. wanted to move to California with his family, Michael Stavarič wanted to go to Canada, etc. For more information about migration literature in Austria, see e.g. Vlasta, S. (2016). Contemporary Migration Literature in German and English: A comparative Study. Leiden, Boston: Rodopi. Or Wonisch, R. (Ed.) (2008). Tschechen in Wien: zwischen nationaler Selbstbehauptung und Assimilation. Wien: Löcker.

3 Struhar participated in a language course, he soon found German-speaking friends and a job in a museum and later in a bookstore, which helped him to integrate more quickly (Cornejo 2008, p. 154). 
(2004 Das Manuskript, 2004 Opuštěná zahrada (German translation: 2020 Verlassener Garten), 2005 Eine Suche nach Glück, 2014 Das Gewicht des Lichts, 2015 Die vertrauten Sterne der Heimat, 2017 Die Verlassenen, 2018 Die Gabe der Hoffnung). ${ }^{1}$ The author wrote poetry at the beginning, and only later he switched to prose. In both genres he wrote the works in Czech at the beginning, only the works published after 2005 were already written in German. ${ }^{2}$

His literary work is strongly influenced by his own migration and life experiences. The main themes of his works include foreignness and exclusion, with the main characters almost always being migrants, or their descendants. Stanislav Struhar describes in a very emotional way how the migrants interact with the culturally foreign society, the loss of home and language associated with it and the loneliness, as well as the common stereotypes, prejudices or even discrimination, with which they are confronted. The role of love and language in the process of integrating migrants into the environment that is foreign to them is also emphasized as being of high importance. In his works, the migrants are hit by personal strokes of fate, most of which are closely related to family relationships. In some cases the death of a loved one is involved, in others the family members are burdened by the consequences of a divorce and the main characters have to come to terms with stepparents.

Stanislav Struhar also describes in his works the different attitudes of the host society towards migrants. It shows the stereotypes and prejudices with which migrants are confronted and what role a love relationship can have for successful integration, which migrants usually develop with a native. In the following, these migration experiences and the positioning of the main migrant characters will be analyzed in more detail using the example of the novels Das Manuskript (2002, Czech original Rukopis 2004), Eine Suche nach Glück (2005) and the short story volume Fremde Frauen (2013). The development in the representation of the migration experiences in the work of Stanislav Struhar should be shown.

In the first work, the protagonists are confronted with rejection (even with physical violence) in their new surroundings, in the other two it is mainly stereotypes and prejudices that they are exposed to in everyday life. It can therefore be said that the portrayal of the experiences of migration in Struhar's later prose works concentrates more on the interior (the feelings

1 More about the life and work of Stanislav Struhar in Balvín 2013, Cornejo 2008, Faltýnek 2008, Iwashita 2004, Iwashita 2008, Nešporová 2015, Schwaiger 2016, Schwaiger 2017, Šilhavá 2020, Šilhavá 2021.

2 One more interesting remark about the author's language change - Stanislav Struhar translated in 2009 a volume of poems by Traude Veran under the title Někteři chtěji vždy znovu príijit (orig. Manche wollen wieder kommen) into Czech. 
and fears of the migrants) and direct violence is avoided. Last but not least, the migrants' attitude to language - both the foreign language and their mother tongue - should be examined in more detail, as it is of particular importance for their self-positioning.

A retrospective narrative style is typical for Struhar's works, the main characters often think back and remember their own past. It is noticeable that this process is always triggered by a particular situation in the present. This leads to a strong intertwining of the present with the past, which also evokes emotions - lively and clearly noticeable, although they are not directly described in the text. This is shown using the example of the following prosaic works.

\section{MIGRATION EXPERIENCES AND RACISM IN THE NOVEL DAS MANUSKRIPT}

The novel Das Manuskript (hereinafter referred to as "M") is Struhar's first prosaic work and was still written in Czech. This novel is a diary of an African, Benjamin, who emigrated to Austria with his parents at the age of 14. At the beginning of the novel, a traumatic experience is described Ben, still a young boy, watched a group of young right-wing extremists in Austria attacking his father and how he died as a result of this attack in combination with his congenital heart defect. Another situation that relates to racism in the host society occurs a few years later when Ben and his Austrian girlfriend Ulrike are watching a performance by young people in an Austrian café-restaurant:

"Auf einer weißen Plane lag eine schwarze Figur, um deren Kopf sich eine Blutlache ausbreitete. Ein Mann, ganz in schwarz gekleidet; sein Gesicht schmerzverzerrt"1 (M, 2002, p. 78).

The young people smile and greet Ulrike and the dark-skinned Ben in a friendly manner, nodding their heads. One can assume that this performance on the street wants to draw attention to the racism that still exists in society and wants to act against it. Despite this intention, this situation is very uncomfortable for Ben, as it awakens in him the traumatic memory of the violent death of his father by the right-wing extremists. He does not greet the young people back. On the contrary, he presses Ulrike to himself as if he wanted to protect her - probably as an expression of his fear, triggered by memories - fear of losing a loved one again.

1 Translations are by the author, unless otherwise attributed:

"On a white tarpaulin was a black figure, around whose head a pool of blood was spreading. A man dressed all in black; his face contorted with pain." 
Ben is attacked several times in the novel because of his different skin color, he is referred to as a "black bastard" (M, 2002, p. 35) and "devil" (M, 2002, p. 36), or compared to an 'uncivilized ape':

"[...] ich befände mich nicht mehr im Urwald, sondern in der Zivilisation."1 (M, 2002, p. 93).

Ben is physically attacked by three men who want to "protect the identity of the people":

"Wir sind keine Rassisten. An dir gefällt uns bloß deine Visage nicht" (M, 2002, p. 102),

it says ironically. In these situations the racism, which unfortunately still exists, comes to the forefront. This ubiquitous racism does not necessarily have to refer to skin color as the obvious and easily identifiable 'foreign'. The trigger can just as well be the 'foreign' language, because of which Ben has problems with the publication of his works, because

“[...] eine Einschränkung auf Grund einer anderen Muttersprache sei als Vor-

stufe zum Rassismus zu betrachten"3 (M, 2002, p. 77),

as Ben's stepfather Hans emphasizes.

Ben's native language makes more of a difference in this work than his skin color. Ben works as a freelance writer. He writes novels, but in his mother tongue, that is, in French. Many related obstacles and problems are portrayed in the novel. Because of his mother tongue, Ben is not perceived as an 'Austrian writer', he has problems with the translations of his works into German and so he cannot have any of them published. Here he is confronted with nationalism and with a kind of 'totalitarianism' in the literary business that only allows native-speaker authors to be authors. He is powerless against this: „Man müsse nicht in einem totalitären Staat leben, um von Formen des Totalitarismus heimgesucht zu werden." ${ }^{4}$ (M, 2002, p. 32)

Nonetheless, Ben stubbornly insists on being or becoming a writer. The employment office advises Ben several times that he has to apply for a job. Ben applies for the job, but purposely acts in a way that he doesn't get the job. For example, he speaks broken German, although he can speak German flawlessly (M, 2002, pp. 98-99).

\footnotetext{
"[...] I would no longer find myself in the jungle, but in civilization."

"We are not racists. We just don't like your look on you."

"[...] a restriction due to a different mother tongue is to be regarded as a preliminary stage to racism."

4 "You don't have to live in a totalitarian country to be afflicted by forms of totalitarianism."
} 
Ben is also confronted with hatred and contempt from those around him and is often met with incomprehension; even in a close circle of friends, which also irritates his girlfriend Ulrike, who is a local Austrian:

"In aufgeregtem Ton setzte sie fort, [...] sie seien das typische Beispiel kleinkarierter Österreicher, die mich als Ausländer tolerierten, vielleicht sogar mochten, aber nur unter der Voraussetzung, dass es mir schlechter ginge als ihnen"1 (M, 2002, pp. 23-24).

Despite all these inconveniences, prejudices or even rejection, Ben feels like an Austrian. Austria is his new home (M, 2002, p. 15), Vienna he calls "his Vienna" (M, 2002, p. 100). However, Ben has a thoroughly ambivalent relationship to this new home, because home is understood as a constricting body shell that (like his body) is not perishable (Iwashita, 2004). That is why he doesn't feel completely free, neither in Vienna, nor in his body: „Ich wollte frei sein - körperlos und heimatlos.“2 (M, 2002, p. 62)

In addition to Ben, another migrant appears in the novel, Martina, who emigrated from totalitarian Czechoslovakia ten years before, but already has Austrian citizenship. Nevertheless, she is still perceived as a migrant and she too has to deal with various stereotypes and problems in Austrian society; and also among her friends when they "make fun of her accent" or when the sarcastic undertone cannot be ignored in their questions: „Als sie eine Kaffeetasse mit einer ähnlichen aus ihrer Kindheit in der ČSSR verglich, hörte ich die sarkastische Nachfrage, ob sie Heimweh habe." (M, 2002, p. 19)

The novel is divided into two parts. The first part is Ben's diary, the second Ulrike's story, because Ben dies as a result of his congenital heart defect (similar to his father) after being involved in an accident. So there are two different first-person narrators in the novel. After his death, Ulrike moves with their child to Abidjan in Côte d'Ivoire, where Ben originally emigrated from with his parents and where the rest of his family still live. She learns French and continues to write Ben's manuscript. She has the opportunity to slip into his skin and take on his role as a 'stranger' in a foreign country - a prerequisite for continuing to write his work: „Erst hier ist mit bewusst geworden, was es bedeutet, in Sprachen zu leben, die nicht die eigenen sind." ${ }^{*}$ ( $M, 2002$, p. 145) Suddenly finding herself in the same situation as Ben before, she begins to understand him better and to feel what he was feeling - she too is now unsettled by the loss of home and language. Nevertheless, she does not

\footnotetext{
1 "In an excited tone she continued, [...] they are the typical example of small-minded Austrians who tolerate me as a foreigner, maybe even like me, provided I am worse off than they are."

2 "I wanted to be free - without a body and a homeland."

3 "When she compared a coffee cup with a similar one from her childhood in the Czechoslovakia, I heard a sarcastic inquiry as to whether she was homesick."

4 "It was only here that I became aware of what it means to live with languages, which are not their own."
} 


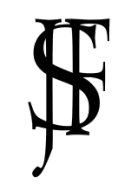

Журнал Фронтирных Исследований. 2021. No 2 | ISSN: 2500-0225

Пограничные исследования в современной европейской литературе | Doi: https://doi.org/10.46539/jfs.v6i2.303

want to return to Austria, although she is asked by her mother to do so, and although she is sometimes in a difficult position as a single woman in a foreign country.

\section{POSITIONING OF THE MIGRANTS AND STEREOTYPES IN THE NOVEL EINE SUCHE NACH GLÜCK}

The second work, the novel Eine Suche nach Glück (hereinafter referred to as "SG"), is not written in diary form, although it is also written in first person and the writing style used in this story is similar to a diary. The main character is also a migrant from former Czechoslovakia and also a writer, named David Kostka. Although he writes his works in German, he has exactly the same problems with their publication as Ben in the novel Das Manuskript. The Austrian editors advise him to write the works in Czech and publish them in the Czech Republic.

David comes from a difficult family background. He never got to know his father and also lost his mother a few years after they emigrated to Austria together. However, he thinks of her constantly, the memories of her haunt him:

"Ihr sanftes Tschechisch bleibt in meinen Erinnerungen lebendig, wie Olmütz" das wir 1984 verließen, und das ich seither nicht mehr sah"2 (SG, 2005, p. 7).

In contrast to Ben in Manuskript, who had no contact with other Africans, for David other migrants at the school in Vienna are important relatives (at least immediately after emigration, later he speaks of no more Czechs):

"Damals waren all die Böhmen, Mährer und Slowaken eine wichtige Unterstützung für mich”3 (SG, 2005, p. 12).

This certainly helped him at the beginning of his new life in Vienna, because he felt lonely and lost, as he admits to his mother shortly after they emigrated together: "Man wird uns hier nie wirklich aufnehmen"4 (SG, 2005, pp. 18-19). But later he finds his new home in Vienna - especially through a love relationship (SG, 2005, p. 17). His girlfriend Astrid (from Vorarlberg) has had a very positive relationship with Vienna since her adolescence, "although she will always feel strange here" (SG, 2005, p. 30). So she also has the 'stigma' of a 'foreigner' or a 'stranger' - something

1 Originally Olomouc, a city in the Czech Republic.

2 "Her gentle Czech remains alive in my memories, like Olomouc, which we left in 1984 and which I have not seen since."

3 "Back then, there were all the Bohemians, Moravians and Slovaks an important support for me."

4 "We will never really be accepted here." 
in common with her Czech friend, as is emphasized again at the end of the story. When Astrid gets pregnant, the following conversation takes place between Astrid and the doctor in the hospital:

„Aber es wird auf jeden Fall ein internationales Kind“,

sagt die Ärztin.

„Meinen Sie wegen meines vorarlbergischen oder seines tschechischen Deutsch?"1 (SG, 2005, p. 113).

This is not the only situation in which the role of languages for integration into society is emphasized. Even a foreign accent can become a stigma and lead to exclusion.

David's positioning between the two languages and two 'homes' is also ambivalent - a position that allows him to become 'at home' in the foreign language and at the same time to preserve his 'otherness' as creating an identity:

"Einerseits fühlte ich mich nicht mehr fremd unter all den Menschen, deren Sprache sich von der meinen unterschied; andererseits schuf meine Muttersprache für mich stets eine Insel, auf der sich mein Herz nach der alten Heimat

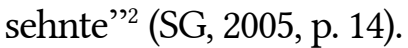

But his attitude towards his mother tongue was not the same from the start; it changes over time. David was initially ashamed as a child when his mother spoke Czech to him at the Christmas market in Vienna and sang a Czech song:

"Wir trugen immer noch die alten Kleider aus der Tschechoslowakei, sprachen leise Tschechisch, blieben vor jedem Stand stehen".

She sang

"[...] leise ein altes tschechisches Weihnachtslied. Ich schämte mich und wich empört von ihrer Seite [...]”3 (SG, 2005, pp. 71-72).

1 "But it will definitely be an international child," says the doctor. "Do you mean because of my Vorarlberg or his Czech German?”

2 "On one hand, I no longer felt a stranger among all those people whose language was different from mine; on the other hand, my mother tongue always created an island for me on which my heart longed for my old home."

3 "We still wore the old clothes from Czechoslovakia, spoke softly Czech, stopped in front of every booth." She sang "[...] softly an old Czech Christmas carol. I was ashamed and left her side indignantly [...]." 
He perceives the 'other' language as a stranger's stigma, indicating that he is a foreigner, a stranger. But later, after the death of his mother, he feels joy when he hears Czech:

"Ein alter Mann sprach mich in gebrochenem Tschechisch an. [...] Seine tiefe Stimme und sein etwas unbeholfenes Tschechisch blieben in meinen Gedanken wie ein heiteres Lied"" (SG, 2005, p. 103).

As an adult, already fully integrated in Austrian society, he perceives the Czech language differently; for him now it is a language that his heart longs for. He no longer has to deny it, but is proud of it and his origins, the Czech language works like a bridge between his old and new homeland.

It often happens in Struhar's works that the partners of the migrants learn or want to learn their mother tongue. Astrid in Eine Suche nach Glück is learning Czech, she speaks to David in broken Czech and finds Czech "erotic" (SG, 2005, pp. 59, 64). She is not only interested in the Czech language, whose foreignness attracts her and which sounds 'exotic' to her ears, but also in the food culture of the foreign country:

"Zunächst werden wir nämlich Tschechisch lernen und anschließend Tschechisch kochen"2 (SG, 2005, p. 60).

This interest in foreign national cuisine and an approach that comes from foreign food is more common in Struhar's works.

Astrid also wants to get to know her boyfriend's country of origin and take a trip to the Czech Republic: "I invite you." The fact that Astrid wants her boyfriend to visit his homeland for the first time since emigrating shows that she is aware of the importance of origin for the identity of every person (and even more of the migrant):

"Du musst endlich zurück zu deinen Wurzeln, sonst wirst du nie frei sein. Lass dich von mir führen, ich bin doch die zweite Hälfte deiner wahren Heimat"3 (SG, 2005, p. 122).

From these lines it can be seen that Astrid is fully aware of the importance of her role in the new (love) relationship. Astrid knows that he must not deny his roots and if he does not return to his roots and his homeland, he will never be able to form new bonds and live 'freely'.

In this work, Struhar also addresses the prejudices of the Austrians against the Czechs (or Slavs). When David's mother, shortly before her death,

1 "An old man spoke to me in broken Czech. [...] His deep voice and his somewhat clumsy Czech stayed in my mind like a cheerful song."

2 "First we will learn to speak Czech and then we will learn to cook Czech."

3 "You have to finally get back to your roots, otherwise you will never be free. Let me guide you, I'm the second half of your true home." 
is not feeling well in a tram, an Austrian woman sitting there remarks to her husband:

"Das sind Slawen, [...], die haben schon immer viel getrunken"" (SG, 2005, p. 111),

although David's mother is sick and not drunk. David is confronted with similar stereotypes in his work. He does get a new job in a bookstore; however, because a customer recognizes by his accent that he is not Austrian, he does not want to be advised by him (SG, 2005, p. 100).

A particularly important topic in this novel is David's attitude to his own situation as a non-native speaker and to the obstacles that he has to overcome in the Austrian literature business. His new girlfriend Astrid works as an editor in a publishing house and you only find out later that their first 'accidental' meeting and getting to know David was not a coincidence at all, but was staged so that he could gain access to the literary business through her.

This shows that the main character in this work is in a different position than Ben in the previously analyzed novel Das Manuskript. David is no longer physically attacked like Ben, his exclusion from society is more of a psychological nature and especially noticeable in his job (as a bookseller and writer). The main difference, however, is that he not only feels a victim and remains a victim, but he fights against it by looking for a girlfriend who can help him with his own professional self-realization and writing career (she is an editor at a major publishing house) and that is why he keeps hiding the fact that he is actually a writer. When Astrid discovers the truth by accident (when she finds his manuscripts), the relationship breaks. Shortly after the separation, however, David finds out that Astrid is pregnant; he goes to see her again and asks her forgiveness. The ending is open, but it can be assumed that since the two are in love, they will stay together. The two main male characters in both works thus find a home in a foreign country through love and start a family, although Ben dies before his son is born.

\section{FOREIGNNESS AND STRANGENESS IN THE VOLUME OF STORIES FREMDE FRAUEN}

In contrast, in the short story volume Fremde Frauen, which consists of two stories, the focus is on being a stranger. In this work, this foreignness and strangeness affect not only the migrants, but also the natives, for whom there is an exclusion from society justified by the others. Struhar shows that

1 "They are Slavs, [...], they have always drunk a lot." 
you don't necessarily have to come from a foreign country to feel like a stranger in society.

In the first story, Bernadette (further referred to as "B"), the main character is Alan Dolezal (formerly Doležal ${ }^{1}$ ), who emigrated from Prague and thinks about his homeland again and again:

"Fast fünf Jahre waren vergangen, seitdem ich meine Heimat verlassen hatte. Manchmal schienen mir die Prager Straßen in unmittelbarer Nähe zu sein, manchmal betrat ich sie in Träumen, fremd nur in meinem Reisepass"2 (B, 2013, p. 7).

And not only the memories of the deserted country, but also of his mother and the sound of her Czech language always haunt him:

"Mutters Tschechisch klang wie mein eigenes leise und nur in meinen Gedanken an"3 (B, 2013, p. 10).

These memories of the Czech language spoken by his mother are very similar to David's memories in the novel Eine Suche nach Glück.

From the first person perspective, the main character Alan explains why he decided to leave Czechoslovakia. As with other main characters, it is not necessarily political reasons or a politically connoted 'lack of freedom' of the characters, but the feeling of a personal restriction and impossibility of free development in the prevailing (family) relationships:

"Von Freiheit träumte ich und war dabei der festen Überzeugung, sie nur in der

Fremde finden zu können"” (B, 2013, p. 8).

The experience of strangeness thus becomes a prerequisite for one's own ego and is not tied to West-East conflicts between the two political systems.

It is later uncovered that Alan fled illegally to Austria and initially lived in a refugee camp. Arriving in a foreign country also means uncertainty, which the newly gained freedom brings with it:

"[...] endlich war ich in der Fremde angelangt, und dennoch überkam mich plötzlich Angst”s (B, 2013, p. 32).

1 The author himself made such a name change. When he became Austrian citizen, he himself asked to change his name from "Struhař" to "Struhar".

2 "Almost five years had passed since I left my homeland. Sometimes the streets of Prague seemed to be very close to me, sometimes I walked in them in my dreams, estranged only in my passport."

3 "Mother's Czech sounded like my own softly and only in my mind."

4 "I dreamed of freedom and was of the firm conviction that it can only be found in a foreign country."

5 "[...] I finally arrived in a foreign country, and yet I was suddenly overcome by fear." 
Alan is a student and at the same time works at a museum, which is of high importance to him.

„[...] meine Kollegen waren die ersten Österreicher, bei denen ich das Gefühl hatte, in diesem Land aufgenommen zu sein. ${ }^{{ }^{11}}$ (B, 2013, p. 15).

During his studies he met Bernadette. She has problems with her stepfather and after an argument she has to move into Alan's apartment, because he is the only one who has a free room. In the beginning there are several unpleasant situations, until the two gradually find each other.

Bernadette comes from a middle-class family and is hostile to foreigners. She argues and scolds the Turks in the park and expresses herself disparagingly not only about the Turks, but also about all women who 'hang out' with them, for example the secretary:

"Die tut, als wäre sie eine Dame, und dabei ist sie mit einem Türken verheiratet"2 (B, 2013, p. 33).

When Bernadette and Alan already know each other a little better, Alan happenes to find a photo in Bernadette's room showing her with two shaved young right-wing radicals. So Bernadette can be described as a young woman with many prejudices against foreigners and acquaintances in the right-wing extremist milieu.

In this work, too, Alan tries to speak only the foreign language and to push the mother tongue out of his life. Several Czechs live in the house where Alan lives, but he avoids exchanging a single word in Czech with them. Even when Alan's shopping bag tears and a Czech neighbor helps him to pick the things up, the two speak to each other in German, which Bernadette is very astonished by (B, 2013, p. 68). And it is not only in contact with his Czech neighbors, where Alan avoids the Czech language; he also refuses to translate German sentences or expressions for Bernadette into Czech when she asks him - Alan pretends not to hear her (B, 2013, p. 58).

When Bernadette and Alan fall in love, Bernadette begins to gradually rethink, break down and change her prejudices. Later she even helps a little Turkish girl who fell off her bicycle in the street (B, 2013, p. 67) because she feels sorry for her.

In the development of Alan and Bernadette's relationship, Czech cuisine once again played an important role. For example, when Alan prepares "topinky", Bernadette tries to learn the Czech word and pronounce

1 "[...] my colleagues were the first Austrians with whom I had the feeling of being accepted in this country."

2 "She pretends to be a lady, and there she is married to a Turk."

3 A Czech dish. These are fried bread slices with garlic, they can also be served with fried eggs, ham, cheese or pickle. 
it correctly (B, 2013, p. 42) - an important phase in Bernadette's development. It is shown that strangeness can be overcome through a love relationship, which is one of the basic statements of Struhar's works.

At the end of the story, both of them stand in front of a ruined castle near Hainburg on the Danube and from there they look at the Slovak capital Bratislava below them. Bernadette wants Alan to finally call his mother, whom he has not seen or spoken to since emigrating:

"Ich [Alan] schloss die Augen, senkte den Kopf und hörte meine Stimme. Mein

Tschechisch bebte"1 (B, 2013, p. 74).

One can conclude from this statement that Alan will finally call his mother. The inner tremor expresses Alan's emotional tension and indicates an imminent outbreak, a liberation of what Alan has suppressed and repressed for a long time - his own origins, his own roots. A similar motif can also be found in the work Eine Suche nach Glück, when Astrid tries to get her friend to visit his homeland, which was abandoned years ago.

The second story, titled Francesca (hereinafter referred to as "F"), is exceptionally told in the third person. The main character is a German named Stefan, who lives in Ventimiglia, Italy, where he followed his love. However, soon after the arrival, she broke up with him. The ambivalence of his positioning is very aptly expressed in the description of the city of San Remo:

"Grenze zwischen der modernen Neustadt und düsteren Altstadt, so stünde Stefan im Niemandsland"2 (F, 2013, p. 78).

But he still doesn't want to go back to Germany:

"Schon bald war das neue Leben, nach dem er sich gesehnt hatte, zu Ende, [...], doch eine Rückkehr nach Deutschland schloss er aus"33 (F, 2013, p. 77).

He has never found anyone in Germany to return to, because he grew up there without ties, in an orphanage. The only place in San Remo that doesn't seem strange to him is the cathedral there. He often goes there to meet German tourists who speak 'his' language. (F, 2013, p. 87) This emphasizes the feeling of togetherness with this place even more.

Stefan starts to work as a salesman in a small goods store. There he accidentally overhears a quarrel between the owner Girardi and his daughter Francesca, who is against the employment of foreigners, because, in her

1 "I [Alan] closed my eyes, bowed my head and heard my voice. My Czech trembled."

2 "The border between the modern new town and the gloomy old town, Stefan would be in no man's land."

3 "The new life he had longed for was soon over, [...], but he ruled out a return to Germany." 
opinion, they are only taking away the work from the locals: "Ein Deutscher ist doch etwas anderes als irgendein Flüchtling", argumentiert der Vater.

"Es kommen immer mehr Ausländer zu uns, die armen nehmen uns die Arbeit weg und die reichen unsere Grundstücke - wie soll denn das weitergehen?" (F, 2013, p. 89)

replies Francesca.

Just like Bernadette at the beginning, Francesca is full of prejudices against foreigners and migrants of all kinds; she is just as cold and arrogant towards Stefan. And like Bernadette, she gradually goes through a development and finally falls in love with Stefan. He drives her several times to see her father, when he is sick in a hospital and she is filling in for him in the shop. The two are gradually getting closer. Thanks to this love affair, Francesca begins to free herself from her prejudices and thanks to Stefan, to see foreigners in a different light. Her father, who at the beginning seems friendly to foreigners and agrees with hiring Stefan in his shop, shows his 'true face' at the moment he discovers the relationship between his daughter and the 'foreigner'. While it is not a problem for him to hire a 'foreigner', it is quite different with his acceptance or tolerance in his own family, i.e. in his private sphere. One is the business, the other is his own family. Stefan and now Francesca encounter the insurmountable barrier of his prejudices, so that in the end she sees no other way out, then to run away from home. She fights for her love and leaves her father, who is the only family for her. That is certainly a great sacrifice on her part. Stefan grew up in an orphanage without a family or close ties to anyone, she loses her whole family (her mother dies and she leaves her father). This makes the two protagonists more alike. Finally, Francesca's father seeks out the lovers and asks for forgiveness. Francesca gets her family (father) back and Stefan gets a new one.

Stefan's friends show compassion for the refugees from the start, as they have to suffer a lot from the loss of their homeland:

"Also ich kann es mir nicht vorstellen, meine Heimat zu verlassen. Ich meine, den armen Flüchtlingen, die nach Italien kommen, denen blieb nichts anderes übrig, aber du bist doch anders, du gehörst nicht zu ihnen"”2 (F, 2013, p. 100).

As in other works by Struhar, Stefan does not suffer from the loss of his homeland, as it has never felt 'at home' in there; he learns Italian without any problems and avoids speaking his mother tongue, even if he occasionally likes

1 "A German is different from any refugee," argues the father. "More and more foreigners come to us, the poor take our jobs away from us and the rich our land - how should this go on?"

2 "Well, I can't imagine leaving my home. I mean, the poor refugees who come to Italy had no other choice, but you're different, you don't belong to them." 
to hear tourists speak it. The Germans in the shop speak broken Italian, but Stefan also speaks consistently Italian with them (F, 2013, p. 103), even though he himself thinks that his Italian is not good enough.

Francesca behaves like Bernadette, Astrid or Ulrike in the previously analyzed works and later, after falling in love with Stefan, learns the language of her partner (F, 2013, p. 141) and loses her prejudices against foreigners and goes gradually through a development process - similar to Bernadette.

\section{CONCLUSION}

To sum up, Stanislav Struhar (himself a migrant) writes about the lives of migrants and their search for happiness (Cornejo, 2008). The stories of the migrants in his works have very specific characteristics - the migrants are not just described as victims. Ben boycotts all offers from the employment office, which can be interpreted as his personal resistance - he doesn't want to give up his dream of being a writer and take on another role that has been imposed on him from the society. David wants to gain access to the Austrian literary business through Astrid, so he wants to use her trust and love for his own benefit. In the narrative Bernadette the main characters even commit an offense. Alan persuades Bernadette to stealing together two packets of chewing gum from a store. They are caught stealing and it is a great shame on Bernadette (B, 2013, pp. 50-51).

The above examples make it clear that migration in Struhar's works always has an ambivalent character. In the country of arrival, the migrants are confronted with various forms of physical and psychological abuse and exclusion. In all three works, the psychological abuse of migrants is that they are always reminded of being foreigners and being perceived as 'strangers', even though they do not feel like ones. The exclusion from the society means they have problems with their professional self-realization, since they often want to express themselves professionally through writing and as non-native speakers have no chance in the publishing houses. Ironicly, this disadvantage is increased by the successful change of language. The protagonists avoid their mother tongue, even when communicating with their partners who have a lively interest in it. They are aware that language represents the stigma of being a stranger and that they are immediately recognizable as such, which is what they want to avoid. They feel at home in the country and want to forget their old home (and the trauma associated with it) as quickly as possible. Their partners, on the other hand, try to learn their mother tongue, as they see it as a bridge - an opportunity to get closer to them and their culture and to understand them better. It should be noted, however, that these are always female characters. This endeavor could be interpreted as an attempt to become a part 
of their partner's new home or to use love to fill out the empty space that has arisen from losing their old home.

What the three analyzed works also have in common is the fact that although the men are migrants who are constantly confronted with the common stereotypes and xenophobic prejudices, it is the women who need to be reassured that they are beloved in the relationship (Struhar, 2002, pp. 62, 66; Struhar, 2005, p. 82; Struhar, 2013, p. 129). This suggests that the migrants occupy a stronger and more stable position in the love relationship than one would assume due to the social disadvantage. They are also the ones who trigger the inner development of their partners (Bernadette and Francesca in Fremde Frauen) or significantly influence them (Ulrike in Manuskript, Astrid in Eine Suche nach Glück). On the other hand, it is the female figures who stand up for their partners when they are being harassed by the police for no reason or if their families fail to understand.

The protagonists' search for love and a functioning relationship can in this case be interpreted primarily as a search for their own position in society, whereby the particular interpersonal relationship means the actual home - a home build from love. Love represents the way into the new society and the new culture. The migrants' partners are the ones who learn how to deal with being a stranger through their relationship. They recognize the importance of language and their own origin for personal development and they represent the role of a bridge between the old and new homeland. As was shown in the example of the volume of short stories Fremde Frauen, the women are being connected, by their immigrant partners, to the language and culture in which they grew up in, even though they do not feel comfortable in it, because they have mostly unpleasant (or even traumatizing) memories. So love has a positive effect on both sides and it helps both partners in their search for happiness, self-realization and self-positioning in society.

\section{References}

Balvín, J. (2013, March 3). I rozdílní lidé můžou najít cestu jeden k druhému (rozhovor) [Even different people can find their way to each other (interview)]. Retrieved from https://www.czechlit.cz/cz/i-rozdilni-lide-muzou-najit-cestu-jeden-k-druhemu/ (In Czech).

Cornejo, R. (2008). 'Eine Suche nach Glück'. Zum Leben und Werk von Stanislav Struhar ["A Search for Happiness". On the life and work of Stanislav Struhar]. In J. Ondráková \& J. Beyer (Eds.), Beiträge zur germanistischen Pädagogik [Contributions to Germanist Pedagogy] (Vol. 3, pp. 41-52). Hradec Králové: Pedagogická faktulta UHK. (In German). 
Faltýnek, V. (2008). Lyrický vypravěč Stanislav Struhar [Lyrical narrator Stanislav Struhar]. Retrieved from http://www.radio.cz/cz/rubrika/knihy/lyricky-vypravec-stanislavstruhar (In Czech).

Iwashita, D. (2004). Stanislav Struhar - Rukopis [Stanislav Struhar-Manuscript]. Retrieved from Literárně hudební rozcestník website: http://knihy.kvalitne.cz/recenze/ struhar.html (In Czech).

Iwashita, D. (2008a). Dnes už myslím a cítím německy (rozhovor) [Today I think and feel German (interview)]. Retrieved from http://www.volvox.cz/o_nas/n_277.php (In Czech).

Iwashita, D. (2008b). Začal jsem ji beze slova koulovat [I started balling her without saying a word]. Retrieved from Volvox Globator website: http://www.volvox.cz/o_nas/ n_286.php (In Czech).

Nešporová, J. (2015). Psát proti neviditelným hranicím [Writing against invisible borders]. Retrieved from ILiteratura website: http://www.iliteratura.cz/Clanek/34599/struharstanislav (In Czech).

Schwaiger, S. (2016). Eine Suche nach Heimat: Stanislav Struhar [A Search for Home: Stanislav Struhar]. In W. Sievers (Ed.), Grenzüberschreitungen. Ein literatursoziologischer Blick auf die lange Geschichte von Literatur und Migration [Border Crossings. A literary-sociological look at the long history of literature and migration] (pp. 235-264). Wien, Köln, Weimar: Böhlau. (In German).

Schwaiger, S. (2017). Stanislav Struhar: "Ich habe nichts Fremdartiges nach Österreich gebracht, außer meiner Muttersprache" [Stanislav Struhar: 'I have brought nothing foreign to Austria except my mother tongue']. In W. Sievers, H. Englerth, \& S. Schwaiger, Ich zeig dir, wo die Krebse überwintern: Gespräche mit zugewanderten Schriftstellerinnen und Schriftstellern [I'll show you where the crabs hibernate: Conversations with immigrant writers] (pp. 171-190). Wien: Edition Exil. (In German).

Šilhavá, G. (2020). Themen und Symbole in den Werken von Stanislav Struhar [Themes and Symbols in the Works of Stanislav Struhar]. In J. Demčišák \& M. Hornáček Banášová (Eds.), Germanistische Forschungsfragen in Trnava, Ustí nad Labem und Wroctaw II [German Studies Research Questions in Trnava, Ústí nad Labem and Wroctaw II] (pp. 73-83). Leipzig: Leipziger Universitätsverlag. (In German).

Šilhavá, G. (2021). Migrationserfahrungen und Positionierungen der Migranten in ausgewählten Werken von Stanislav Struhar [Migrant experiences and positioning of migrants in selected works by Stanislav Struhar]. In G. Schuppener, V. Jičínská, \& M. Kałasznik (Eds.), Germanistische Forschungsfragen in Trnava, Ustí nad Labem und Wroctaw II [German Studies Research Questions in Trnava, Ustí nad Labem and Wroctaw II] (pp. 93-105). Leipzig: Leipziger Universitätsverlag. (In German).

Struhar, S. (1999). Der alte Garten: Gedichttrilogie [The Old Garden: Trilogy of Poems] (J.-P. Abraham, Trans.). Linz, Wien: Resistenz-Verlag. (In German).

Struhar, S. (2002). Das Manuskript. Roman [The Manuscript. Novel] (A. Leben, Trans.). Klagenfurt,Celovec: Drava. (In German).

Struhar S. (2004). Opuštěná zahrada: Román [The Abandoned Garden: A novel]. Praha: Volvox Globator. (In Czech). 
Struhar, S. (2005). Eine Suche nach Glück: Roman [A Search for Happiness: Novel]. Klagenfurt: Kitab-Verlag. (In German).

Struhar, S. (2013). Fremde Frauen: Zwei Erzählungen [Strange Women: Two Narratives]. Klagenfurt,Celovec: Wieser. (In German).

Struhar, S. (2014). Das Gewicht des Lichts: Roman [The Weight of Light: Novel]. Klagenfurt,Celovec: Wieser. (In German).

Struhar, S. (2015). Die vertrauten Sterne der Heimat: Roman [The Familiar Stars of Home: Novel]. Klagenfurt,Celovec: Wieser. (In German).

Struhar, S. (2016). Farben der Vergangenheit: Erzählungen [Colours of the Past: Narratives]. Klagenfurt,Celovec: Wieser. (In German).

Struhar, S. (2017). Die Verlassenen: Roman [The Forsaken: Novel]. Klagenfurt,Celovec: Wieser. (In German).

Struhar, S. (2018). Die Gabe der Hoffnung: Roman [The Gift of Hope: Novel]. Klagenfurt,Celovec: Wieser. (In German).

Struhar, S. (2021). Farben der Zukunft: Erzählungen [Colours of the Future: Narratives]. Klagenfurt,Celovec: Wieser. (In German).

Veran, T. (2009). Někteří chtějí vždy znovu přijít [Some always want to come again] (Stanislav Struhar, Trans.). Praha: Dolphin. (In Czech).

Vlasta, S. (2016). Contemporary Migration Literature in German and English: A comparative Study. Leiden, Boston: Rodopi.

Wonisch, R. (Ed.). (2008). Tschechen in Wien: Zwischen nationaler Selbstbehauptung und Assimilation [Czechs in Vienna: Between national self-assertion and assimilation]. Wien: Löcker. (In German).

\section{Список литературы}

Balvín, J. (2013, March 3). I rozdílní lidé můžou najít cestu jeden k druhému (rozhovor) [Even different people can find their way to each other (interview)]. Retrieved from https://www.czechlit.cz/cz/i-rozdilni-lide-muzou-najit-cestu-jeden-k-druhemu/ (In Czech).

Cornejo, R. (2008). 'Eine Suche nach Glück'. Zum Leben und Werk von Stanislav Struhar ["A Search for Happiness". On the life and work of Stanislav Struhar]. In J. Ondráková \& J. Beyer (Eds.), Beiträge zur germanistischen Pädagogik [Contributions to Germanist Pedagogy] (Vol. 3, pp. 41-52). Hradec Králové: Pedagogická faktulta UHK. (In German).

Faltýnek, V. (2008). Lyrický vypravěč Stanislav Struhar [Lyrical narrator Stanislav Struhar]. Retrieved from http://www.radio.cz/cz/rubrika/knihy/lyricky-vypravec-stanislavstruhar (In Czech).

Iwashita, D. (2004). Stanislav Struhar - Rukopis [Stanislav Struhar-Manuscript]. Retrieved from Literárně hudební rozcestník website: http://knihy.kvalitne.cz/recenze/ struhar.html (In Czech). 
Iwashita, D. (2008a). Dnes už myslím a cítím německy (rozhovor) [Today I think and feel German (interview)]. Retrieved from http://www.volvox.cz/o_nas/n_277.php (In Czech).

Iwashita, D. (2008b). Začal jsem ji beze slova koulovat [I started balling her without saying a word]. Retrieved from Volvox Globator website: http://www.volvox.cz/o_nas/ n_286.php (In Czech).

Nešporová, J. (2015). Psát proti neviditelným hranicím [Writing against invisible borders]. Retrieved from ILiteratura website: http://www.iliteratura.cz/Clanek/34599/struharstanislav (In Czech).

Schwaiger, S. (2016). Eine Suche nach Heimat: Stanislav Struhar [A Search for Home: Stanislav Struhar]. In W. Sievers (Ed.), Grenzüberschreitungen. Ein literatursoziologischer Blick auf die lange Geschichte von Literatur und Migration [Border Crossings. A literary-sociological look at the long history of literature and migration] (pp. 235-264). Wien, Köln, Weimar: Böhlau. (In German).

Schwaiger, S. (2017). Stanislav Struhar: "Ich habe nichts Fremdartiges nach Österreich gebracht, außer meiner Muttersprache" [Stanislav Struhar: 'I have brought nothing foreign to Austria except my mother tongue']. In W. Sievers, H. Englerth, \& S. Schwaiger, Ich zeig dir, wo die Krebse überwintern: Gespräche mit zugewanderten Schriftstellerinnen und Schriftstellern [I'll show you where the crabs hibernate: Conversations with immigrant writers] (pp. 171-190). Wien: Edition Exil. (In German).

Šilhavá, G. (2020). Themen und Symbole in den Werken von Stanislav Struhar [Themes and Symbols in the Works of Stanislav Struhar]. In J. Demčišák \& M. Hornáček Banášová (Eds.), Germanistische Forschungsfragen in Trnava, Ustí nad Labem und Wroctaw II [German Studies Research Questions in Trnava, Ustí nad Labem and Wroctaw II] (pp. 73-83). Leipzig: Leipziger Universitätsverlag. (In German).

Šilhavá, G. (2021). Migrationserfahrungen und Positionierungen der Migranten in ausgewählten Werken von Stanislav Struhar [Migrant experiences and positioning of migrants in selected works by Stanislav Struhar]. In G. Schuppener, V. Jičínská, \& M. Kałasznik (Eds.), Germanistische Forschungsfragen in Trnava, Ustí nad Labem und Wroctaw II [German Studies Research Questions in Trnava, Ustí nad Labem and Wrocław II] (pp. 93-105). Leipzig: Leipziger Universitätsverlag. (In German).

Struhar, S. (1999). Der alte Garten: Gedichttrilogie [The Old Garden: Trilogy of Poems] (J.-P. Abraham, Trans.). Linz, Wien: Resistenz-Verlag. (In German).

Struhar, S. (2002). Das Manuskript. Roman [The Manuscript. Novel] (A. Leben, Trans.). Klagenfurt,Celovec: Drava. (In German).

Struhar S. (2004). Opuštěná zahrada: Román [The Abandoned Garden: A novel]. Praha: Volvox Globator. (In Czech).

Struhar, S. (2005). Eine Suche nach Glück: Roman [A Search for Happiness: Novel]. Klagenfurt: Kitab-Verlag. (In German).

Struhar, S. (2013). Fremde Frauen: Zwei Erzählungen [Strange Women: Two Narratives]. Klagenfurt,Celovec: Wieser. (In German).

Struhar, S. (2014). Das Gewicht des Lichts: Roman [The Weight of Light: Novel]. Klagenfurt,Celovec: Wieser. (In German). 
Struhar, S. (2015). Die vertrauten Sterne der Heimat: Roman [The Familiar Stars of Home: Novel]. Klagenfurt,Celovec: Wieser. (In German).

Struhar, S. (2016). Farben der Vergangenheit: Erzählungen [Colours of the Past: Narratives]. Klagenfurt,Celovec: Wieser. (In German).

Struhar, S. (2017). Die Verlassenen: Roman [The Forsaken: Novel]. Klagenfurt,Celovec: Wieser. (In German).

Struhar, S. (2018). Die Gabe der Hoffnung: Roman [The Gift of Hope: Novel]. Klagenfurt,Celovec: Wieser. (In German).

Struhar, S. (2021). Farben der Zukunft: Erzählungen [Colours of the Future: Narratives]. Klagenfurt,Celovec: Wieser. (In German).

Veran, T. (2009). Někteři chtějí vždy znovu přijít [Some always want to come again] (Stanislav Struhar, Trans.). Praha: Dolphin. (In Czech).

Vlasta, S. (2016). Contemporary Migration Literature in German and English: A comparative Study. Leiden, Boston: Rodopi.

Wonisch, R. (Ed.). (2008). Tschechen in Wien: Zwischen nationaler Selbstbehauptung und Assimilation [Czechs in Vienna: Between national self-assertion and assimilation]. Wien: Löcker. (In German). 